UDC 2-457:165.191

\title{
MYTHOLOGY AND MYTHIC INSULT OF MATERNITY IN DISCOURSES AND NARRATIVES IN MODERN PHILOSOPHY AND CULTURE
}

\author{
(C) MAKIESHYNA,YULIIA \\ Prydniprovsk State Academy of Physical Culture and Sport(Dnipro, Ukraine) \\ E-mail: makeshina@i.ua ORCID 0000-0002-2879-2930.
}

Lemma. The relevance of the research is that the mythological and mythological images existing in the culture ("woman-mother ", "woman-worker", etc.), which produce a "natural" world for us, are analyzed while eliminating from the field of vision the alternative possibilities of its device. By problematizing this evidence, comprehending the possible values excluded by the authorities, it is possible to foresee the consequences of certain discursive concepts, while destroying their ideological closeness, "naturalness" and self-evidence of the proposed designs. The formulation of the task consists in the philosophical comprehension of the specifics of the conceptualization of motherhood as a complex semantic field, which is determined by the nature of gender relations. The subject of the research consists of the transformation of social forms and dispositive philosophical problems of motherhood, their representation in the discourses and narratives of modern philosophy and culture. Analysis of recent research and publications. Important for our study are the works of J. Butler, S. Raddick, L. Irigarey, E. Sixu, J. Kristeva C. Lemert, E. Jeremiah, P. Deicher, L. Nicholson, and others, which determine the study of maternity from the point of view of the problems of identity / subjectivity, which is one of the main theoretical areas of postmodernity. The researchers of gender, considering the postmodern impulse, tend to deconstruct female identity, biology and "materiality", despite the "eternal secret" of the essential body.

Key words:maternity, subjectivity, representation, discoursive practice, performativity.

Isolation of unexplored parts of the general problem. Only a few basic ideologies of motherhood are analyzed that create the "objectivity" of our ideas and role expectations in the sociocultural context of postmodern discursive transformations of both motherhood in particular and parenthood in general.

Methodology of the research. This study uses both the theory of gender, its influence on the sociocultural context of motherhood and its interpretation, and also relies on postmodern methodology, including phenomenological-hermeneutic, interpretative approaches.

Scientific novelty of research. Today there is a problem of deconstruction of the mythology of modern motherhood, modern images of a woman mother are supported by the influence of patriarchal discourses, including in modern media culture. This study examines their impact on the ethical and aesthetic aspects of motherhood.
Statement of the chief material. It is analyzed that "mother" is not only a physical figure or an immanent identity; "mother" is a symbol occupying an incomparable place in language and culture. The complex structure of gender social reality is indicated, which cannot be explained with the position of traditional binary oppositions ("culture / nature", "spirituality / materiality", etc.), and thatnecessarytoexchange withintellection at the terms of differential digestion.It is proved that the political discourse with its monopoly on "symbolic violence" forms fixed knowledge, thus appearing images of "woman mother", "Bereginy", "motherland", etc.

Conclusion. Transformations in the sphere of the maternity family are inscribed in the global context of the "post-modern" world, and those changes in the maternal behavior patterns around which the "life project" of a woman is being built are closely related to them. 
The problem is presented in general terms and its links with important scientific or practical tasks.In Ukrainian society, as in other modern societies, certain changes in marriage and family behavior began to beconsidered not only in the context of demographic transformations, but also in connection with the increasing pluralization of family relations, inextricably linked with the general "post-paradigmatic" pluralization of the postmodern society. Thus, the philosophical analysis of the overall gender policy in its aspects of postmodern processes is also a necessary condition for a meaningful study of conceptual directions and empirical data that have a relation - explicitly and implicitly - to the phenomenon of motherhood.

The relevance of the topic researchof the phenomena of motherhood is due to the social challenges of the first decade of the 21 st century, which, by changing the gender regimes, led to the formation of new institutional tendencies in motherhood and caused a new flow of their reflexive understanding. The problem of a harmonious combination of professional, parental and conjugal roles by a woman is currently particularly controversial, requiring conceptual reflection in many areas of modern theory, including, of course, philosophy. On the one hand, representatives of the gender approach, reflecting on the problem of motherhood, advocate the expansion of the boundaries of personal choice and alternative life styles, on the other hand, the traditional discourse of "right motherhood" continues to emphasize patriarchal models, suggesting that the mother's responsibility for the well-being of her children and care they are the fundamental components of a full-fledged female identity. On the other hand, it is obvious that the changes in the gender regimes that have occurred in recent years in our country have affected the growth of economic and organizational resources that have led to a significant increase in the indicators of women's paid employment.

As known, women constitute today the majority of university students, invading such traditionally "male" spheres as heavy engineering, computer technology, civil engineering, military science, etc. Such changes inevitably entail political transformations, influencing in general, on the participation of women in the political and civil structures of Ukrainian society. At the same time, one of the most important concepts in the gender regimes of the Ukrainian society remains the distinction between the public, public, and private, domestic spheres of life of men and women, forms of gender relations, both in the family and in society.

Official state discourse says that motherhood, as the main institutionally recognized mechanism of family functioning, occupies one of the important places in "agenda" of modern Ukrainian politics. However, the very formulation of the issue indicates a certain stable tension existing between the main subjects of this problem: power and a woman-mother. There are still various types of simulation and manipulation models and technologies that are designed to smooth problems and embellish the real situation. An indisputable confirmation of the fact that the Ukrainian society is focused on complex gender changes, consistent with European norms and standards, is a series of government decrees, adopted laws and relevant state acts. At the same time, it should be noted that: Maternal gender strategies have different implications in our country and Western European countries; the reduction of governmental materialist programs placed an additional burden on women in Ukraine, who had to take unpaid social security and family care - functions that had previously been considered public. It should also be noted: despite the researchers' particular attention to the place and role of men in the home, private sphere, the family and those activities associated with it are still "women's spheres" with an impressive disproportionate gap.

Scientists say: "postmodern" motherhood is diverse and not always directly related to marriage and bloodrelated relationships. It is increasingly filled with values such as the desire for selfrealization, understanding and building a 
trusting relationship between mother and children. A person is not satisfied with his role as a "person" if he does not feel himself to be a creator. Of course, among the many ways of such self-realization, the most natural for a woman is to have children, take care of their "creatures" and love them. The mother in the child "leaves" for her own limits, her love for the child gives her meaning and significance, and this love is, according to E. Fromm, the most difficult form of love: it is all the more deceptive, the more "natural" it seems.

Today, this approach is reflected in the theory of feminism, which raises a very interesting layer of problems related to motherhood. The scientific works of gender researchers discuss the problems of the mother's personality, its position in the family and society; analyze such new topics as maternal aesthetics, pregnancy problems, childbirth, maternal "practices", etc. The theoretical discourse of maternity research includes both the feminist theory, gender studies, and philosophy, political and social sciences, psychoanalysis and semiotics, which received rapid development in postmodernism. The dissatisfaction with the essentialism of the early positions of feminism led the researchers of gender to recognize the plurality of points of view and their subjectivity; the postmodern view of the subject's identity shifted theoretical reasoning to philosophical and epistemological problems that brought the feminist theory closer to postmodern views.

Stressing the relevance of such studies, scientists write that new "dimensions" of motherhood (pregnancy, childbirth, feeding a newborn, etc.) are central to human existence, but are rarely discussed in the philosophical canon. Perhaps, the latter is connected with those areas of "closeness" that political discourses create (P. Bourdieu), but in our case it is important that such a "closed area" forms fixed values that seem completely natural. Mythologies and myths ("mother-woman", "woman-worker", etc.) produce a "natural" world for us, while eliminating from the field of vision the alternative possibilities for its organization. By problematizing this evidence, comprehending the possible values excluded by the authorities, it is possible to foresee the consequences of certain discursive concepts, destroying their ideological closeness, "naturalness" and self-evidence of the proposed designs.

It should be noted that the predominant understanding of gender in social sciences as constitutive simultaneously on multiple levels, including the micro-level of relations and the macro level of changes in social structures, undoubtedly goes along with the philosophical concepts of gender with emphasis on the fact that gender relations have ontological depth that should be analyzed not only in the institutional spheres of the economy or politics, but primarily in the philosophical reflection of interrelated gender relations and gender.

The analysis of the basic ideologies of motherhood, creating the "objectivity" of our ideas and role expectations, acquires special importance in the sociocultural context of postmodern discursive transformations of both motherhood and parenthood in general. Undoubtedly, the study of gender aspects of these transformations is interdisciplinary, but as an independent philosophical phenomenon, motherhood is not fully conceptualized category. A fundamental development of the theoretical material of motherhood is necessary on the basis of an analysis of the specifics of gender society, the philosophical reflection of the historical epochs in question, as well as the corresponding representations in the concepts, discourses and narratives of culture.

In Ukrainian society, as in other modern societies, certain changes in marriage and family behavior began to be considered not only in the context of demographic transformations, but also in connection with the increasing pluralization of family relations, inextricably linked with the general "post-paradigmatic" pluralization of the postmodern society. Thus, the philosophical analysis of the overall gender policy in its aspects of postmodern processes is also a necessary condition for a meaningful study of conceptual directions and empirical data that have a relation - 
explicitly and implicitly - to the phenomenon of motherhood.

The phenomena of motherhood, like any other complex socio-cultural phenomenon, needing active philosophical reflection, requires a comprehension from the theoretical positions of postmodern discourse, and here the subject of attention are the works of M. Foucault, J. Derrida, and J. - F. the Lyotard, J. Deleuze, Y. Kristeva, F. Jameson, etc. Specificity of the problem being investigated is determined by the scientific approaches that have developed in modern gender theory. If the feminist thought of the 1970s demonstrated "renunciation" of motherhood (B. Friedan, S. Firestone, K. Millet, C. Delphi), then in the 1980s, gender studies represent a policy of "restoring" motherhood (E. Rich, N. Chodorou, D. Dinnerstein, S. Ruddik - in America, L. Irigara, E. Siksu, J. Kristeva - in France). The theoretical stage of the end of the 20th century, which continues today, is both a conceptual expansion and a challenge thrown by the theories proposed earlier (J. Butler, E. Jeremiah, M. Chandler, P. Deicher, L.Nicholson, C. Lemert, T. Moi and many others). Motherhood, viewed from the point of view of Butler is a practice, and maternal subjectivity is not static, it is always in the process, it is constantly constructed, it is always "performativity".

Turning towards the performativity, which is so important in this analysis, it is necessary, in our opinion, to dwell on some definitions. "Cultural performance" is, as the well-known sociologist JS Alexander believes, a social process by which actors, individually or in interaction with each other, expresses the meaning of their social situation. This meaning may or may not be by the way subjectively shared; this is the meaning in which they as social actors (consciously or unconsciously) want others to believe [1].

Of particular importance for this analysis are works showing that the performance of the mother's functions by the woman is the central and defining characteristic of the social organization of gender and underlies the reproduction of male domination (E. Kis, S. Ruddik, E.
Fergusson and many others). It should be noted that the indisputably weighty contribution made by psychoanalysts and sociologists (N. Chodorou, S. Ruddik, S. Böhm, W. Simon, M. Kimmel, etc.), which conceptions also had a significant impact on the analysis of the phenomenon of motherhood, scientific interpretation of the problems of maternity, presented in this article.

The desire to systematize existing theories relating to the interpretation of the phenomenon of motherhood can be traced in the works of the Ukrainian researchers of the gender I. Zherebkina, A. Vishnevsky, O. Kis, L. Bondarenko, A. Tolstokorova, T. Zhurzhenko, E. Lutsenko, O. Kikinejdi.

The phenomenon of motherhood, like any other complex socio-cultural phenomenon, needing active philosophical reflection, requires a comprehension from the theoretical positions of postmodern discourse, and here the subject of attention are the works of M. Foucault, J. Derridaand J.-F. Lyotard, J. Deleuze, Yu. Kristeva, F. Jameson, A.V. Guligi, A.L. Gurevich, S.V. Shevtsova, V.I. Pronyakin and other modern researchers. The philosophical approach to the analysis of gender relations in motherhood cannot be comprehended in isolation, outside its conceptual connection with the anthropological, culturological, historical developments of such scientists as V. Gorsky, P. Gnatenko, S. Krymsky, V. Palaguta, N. Khamitov, N. Troyan , N. Taran, V. Tabachkovsky, S. Pavlychko, O. Kis, T. Gundorova and others.

In the last two decades, feminism and mass culture have come closer than ever before. Analysts view this phenomenon from different points of view, but the main reason is still in the unprecedented spread of pop culture itself. Today, we have much more mass "examples" and just for viewing, for scientific research, and for postmodern deconstruction. Prints for women, glossy magazines represent pop culture and as a discourse, and as a source of inspiration, and as a welcome pastime. Television includes in its network more "women's views", which are actually a "look" of men, the Internet presents more blogs and social networking 
pages that not only critically analyze the existing pop culture, but also create their own.

In the "new" pop culture, according to T. Vlasova, the dividing line between the political and the mass has disappeared: pop culture informs us about political issues where there seems to be no close pop culture; and at the same time it makes us see how something purely entertaining becomes a political problem [7]. Here, as before, the influence of the "male gaze" on how women see pop culture and how they see themselves in it remains very important. The idea of a "man's view" is that when we look at a work of art or on a movie / TV screen, we see images the way a man sees them, not at all fiction of feminists: these images are created for consideration by men. That is, women see themselves as men, and this determines not only the relationship between men and women, but also the attitude of women to themselves. "Observer" in a woman is of a masculine gender, "observed" is female. The latter turns a woman into an object, most often in the object of sight - "sight", "sight" [2].

Pop culture has always been closely associated with commerce; a huge segment of the advertising business has always been addressed to women. In most cases, his messages taught women to always "be on guard" in order to preserve their most important quality - their appearance. Women, created by men, are great pretenders, "creators of illusions". And this concerns not only stereotyped behavior, stereotyped concept of the inner world of a "real woman", but, above all, her appearance, her body. Every woman knows that despite all her achievements, she is a failure if she is not beautiful. Thirty years ago it was enough to look attractive, today a woman should have a young body, including all its parts. Whichever woman is, whatever she does, she must look young: it is a mantra that all the media repeat in every way countless times every day. Of course, in such a "fitness regime", such a "youth program" for a lifetime, pregnancy, the birth of a child (especially a few children), breastfeeding, etc. do not fit. In a culture that retains the right to humiliate women who are considered ugly, the desperate desire to "be beautiful" tends to prevail over the desire to have children. Women in a bikini on billboards, parts of a female body - lips, chest, eyes - on the covers of magazines and in advertising video sequences; women on television, promising that the "product" in their hands will make you smaller, thinner, longer, smoother, more elegant - the revelry of images fascinates. The image of a pregnant woman, occasionally appearing in the media, occupies a certain marginal place.

The problem of abortion in pop culture is also, in our opinion, not a prohibited, but undesirable topic, and it is connected mainly with several narratives. This, for example, as $\mathrm{O}$. Kis notes, a narrative of a "ghost child", a narrative that can be called "the fire of hell and the smell of sulfur," a psychoanalytic narrative of the tortures of a heroine who accepts (or does not accept) a similar decision, etc. [9].

Disdainful attitude towards mothers seems to be a permanent feature of patriarchal societies, but one cannot help but notice that at the beginning of the third millennium contempt for the "Mother" acquired a new dimension related to homosexual practices and pansy boy culture [13]. But still women - and only women bear children, give birth to them in agony; feed them with breast milk (their body!) And - are preparing to lose them. The old way to deprive a woman of her sons meant to take them to the army, the factory, the mine, etc., and the daughters into the family of the men for whom they married. It is also important that the "mother" is not an alternative to a career; a woman who gave herself to motherhood today also must remain "in shape", always young and beautiful, if she wants to be loved, including her children.

It should be noted that a biological family consisting of a mother and a child is very vulnerable, it needs protection and care: mothers need means of subsistence, financial, physical and moral support. The famous British feminist G. Grier writes that if she had previously argued that motherhood should not be seen as a substitute for a career, today she is 
convinced: motherhood should be viewed as a $100 \%$ career alternative, that is, as a paid job, as an alternative to another paid work. The choice, whether to continue to live, giving all his time to family and home, should be the choice of the woman herself. The benefits of the state with such investment in motherhood, according to the researcher, are indisputable [3].

Scientists say: "postmodern" motherhood is diverse and not always directly related to marriage and bloodrelated relationships. It is increasingly filled with values such as the desire for selfrealization, mutual understanding and the building of a trusting relationship between mother and children. What changes are taking place in "attitudes" and "patterns" in the sphere of motherhood? If we turn to the discourses of science and, in particular, philosophy, we should note the growth of studies devoted to the problems of pregnancy, the birth of children, "maternal practices", etc. The scientific works discuss issues of the mother's personality, her position in the family and society, such new topics as maternal aesthetics are raised, old ones are deepened - motherhood as an existential confrontation of death $[10,11]$.

Since the publication of the fundamental book by Sara Raddik, "Maternal Thinking" (1989), it has been a quarter of a century already and, of course, today post-feminist philosophers are reviewing many "subjects" in maternity, certainly paying tribute to gender researchers of the late 20th century, paved the way in the dark forest of paternalism, which sanctified a lot of mother themes "[5, p. 2]. The theoretical discourse of research includes feminist philosophy, and existentialism, phenomenology, political and social theories. Stressing the relevance of such studies, scientists write that the "new dimensions" of motherhood (pregnancy, childbirth, breast-feeding, etc.) are central to human existence, but are rarely discussed in the philosophical canon. Today, the "gender situation" is undoubtedly characterized by the ongoing transformation of the gender regime in "public-private" opposition, the transition of women from the domestic sphere to social and political life, but this process is far from complete even in the "global North", not to mention the "South" [9]. In countries where the gender regime is more "home-based", the materialist thinking, the feminist feminism strategies have other implications in comparison with those where the gender regime has already taken-or accepts-public forms. And this difference remains relevant. Still in many countries, one of the reasons why the exclusion of women from the spectrum of supposedly universal provisions goes unnoticed is that the division of the private and public spheres is represented in the liberal theory as if it applied equally to all persons - men and women [14].

As noted above, one of the most important contributions of gender researchers in the last third of the twentieth century. in feminist theory is a new definition of the concept of "political", which includes both public and private spheres. The notion that one can make an easy and simple distinction between political and personal, public and private remains today the basis for much of political theory. As feminist theorists have shown, this fundamental division is based on the culture of patriarchy, and it cannot remain unchanged today, when the long era of patriarchy comes to an end [6].

Today, as before, women continue to resist the patriarchal domination of men, asserting their right to "power" in the family as a mother [8]. At the same time, feminism continues to demand full citizenship for women, regardless of family relations. Like the "materialists" of the early feminist movement, modern women insist on their subjectivity as a mother, defending the interests of their family. Historian T. Kaplan calls such a maternal power "female awareness" in contrast to feminist awareness [4]. When women act on behalf of their assigned gender identity to improve their lives and the lives of their families, this does not necessarily means requiring the privileges that men have. The political scientist-feminist M. Moligno uses the term "practical gender interest" to describe the "road map" of those researchers who adopt a gender hierarchy, but try to solve specific 
problems while making moral demands to motherhood [13].

Nevertheless, whatever the "label" of the success of feminist females, the demand for justice for the mother can be found today everywhere: in Peru, and in Los Angeles, and in the settlements of Costa Rica [3]. Feminism, on the whole, has always demonstrated mixed reactions to the materialists' policies: from essentialism (S. Ruddick or K. Gilligan) to the complete rejection of cultural submission as a mother (S. De Beauvoir) [9]. But advocates and critics of "women's awareness" of motherhood should, as it seems, always remember that the overwhelming majority of women in the world still continue to fulfill the family functions of the household and motherhood, and for so many women their "social authority" is still based on the identity of the mother. And in Europe, and in North America, and in Japan, women continue to urge society to adequately assess maternal work, even if women have access to education, property, political participation. The demands of the very first feminists still receive a response all over the world. Despite the politicization of all forms of feminism, the struggle for gender equality continues to emphasize the struggle for the rights of the mother woman - both in society and in the family.

Conclusion. The official interpretation of the discourse of the family and motherhood, in our view, is not homogeneous, and the role of modern culture is to show the importance of the patterns and motherhood narratives recorded in the minds of individuals, the role of discourse in interpreting the various forms of the life experience of the mother woman. It should be noted that in the European postSoviet space, in this discourse, there are still several myths that not only affect the normative view of the mother, but also legitimize the goals and instruments of the state's family policy. Thus, the task is to identify the gender strategies of postmodernism in their close connection with the context of everyday problems of the mother woman of the early 21 st century.

\section{СПИСОК ВИКОРИСТАНИХ ДЖЕРЕЛ}

1. Alexander, J. C. Social Science as Reading and Performance: A Cultural Sociological Understanding of Epistemology // European Journal of Social Theory. 2009. № 12(1). P. 21 41.

2. Freedman, E. No Turning Back. New York :Ballantaine Books, 2003. 446 p.

3. Greer G. The Whole Woman / Germaine Greer.- London : Black Swan, 2007. - 452 p.

4. Kaplan, T.Crazy for Democracy: Women in Grassroots Movements. New York and London : Routledge, 1997. 243 p.

5. Lintott, S. Philosophical Inquiries into Pregnancy, Childbirth, and Pregnancy: maternal subjects. London, NewYork :Routledge, 2012. 268 p.

6. Kremer, M. The Politics of Ideals of Care: Danish and Flemish Child Care Policy Compared / Monique Kremer // Social Politics: International Studies in Gender State and Society. Vol. 13.2006. № 2.P. $261-285$.

7. Власова, Т. И.Гендер и феминистская теория в философии постмодерна.Днепропетровск : Изд-во Маковецкий, 2011. 124 с.

8. Гендер и власть: семья, общество, государство. М. : Ин-т Африки РАН, 2008. $432 \mathrm{c}$.

9. Кись, О. Проблемы (ре)конструкции истории женщин в Украине: акторы, авторы, нарративы // Гендерное равноправие в России. СПб. : Алетейя, 2008. С. 155 - 162.

10. Макешина, Ю.В. Концепт семьи в логике дихотомии «публичное - частное» // Грані. Науково-теоретичний і громадсько-політичний альманах. - № 12 (103). Д., 2013. C.148-153.

11. Макешина, Ю.В. Либеральныйфеминизм и психоанализ: обществоVS. // Вісник Дніпропетр. нац. ун-ту. Сер. : Філософія. Соціологія. Політологія. Вип. № 24 (2). Том 
22, № 9/2: Д. : ДНУ ім. О. Гончара, 2014. С.63-68.

12. Макешина, Ю.В. Личность и феномен материнства в феминистском дискурсе постмодерна // Українознавчий альманах. Вип.16. К. : КНУ, 2014. С.33-36.

13. Макешина, Ю.В. Репрезентация материнства в феминистской философии Ю. Кристевой// Грані. Науково-теоретичний і громадсько-політичний альманах. № 11 (115). Д. , 2014. С. 29-33.

14.Печерская, Н.Мифология родительства: анализ дискурсивного производства идеальной семьи // Журнал исследований социальной политики. Т. 10. 2012. № 3. C. $323-342$.

\section{REFERENCE}

1. Alexander, J. (2009). Social Science as Reading and Performance: A Cultural Sociological Understanding of Epistemology // European Journal of Social Theory. № 12(1). P. 21-41 [in English].

2. Freedman, E. (2003). No Turning Back. New York:Ballantine Books. P.446[in English].

3. Greer G. (2007). The Whole Woman / Germaine Greer. London: Black Swan, 2007. P. 452 [in English].

4. Kaplan, T. (1997). Crazy for Democracy: Women in Grassroots Movements. New York and London: Routledge. P. 243[in English].

5. Lintott, S. (2012). Philosophical Inquiries into Pregnancy, Childbirth, and Pregnancy: maternal subjects. London, New York:Routledge. P. 268 [in English].

6. Kremer, M. (2006). The Politics of Ideals of Care: Danish and Flemish Child Care Policy Compared // Social Politics: International Studies in Gender State and Society. Vol. 13.№ 2. P.261-285 [in English].

7. Vlasova, T. (2011). Gender and feminist theory in postmodern philosophy. Dnipro: Makovetsky Publishing House. P.124 [in Russian].

8. Gender and power: family, society, state. - Moscow: Institute of African Studies, RAS, 2008. P.432 [in Russian].

9. Kis, O. (2008). Problems (re) the construction of the history of women in Ukraine: actors, authors, narratives // Gender Equality in Russia. - St. Petersburg. : Aleteyya. P.155 162 [in Russian].

10. Mashishina,Y. (2013). The concept of the family in the logic of the dichotomy "public - private" // Grani. Scientific-theoretical and public political almanac. No. 12(103). D. P.148153 [in Russian].

11.Mashishina,Y. (2014). Liberal feminism and psychoanalysis: society VS. // AnnouncerDnipro State University. Ser.:Philosophy. Sociology. Politology. Edd. No. 24 (2). Volume 22, No. 9/2: D.: DNU named after O. Gonchar. P.63-68.

12. Mashina, Y. (2014). Personality and the phenomenon of motherhood in the feminist discourse of postmodern // Ukrainian Studies. Edd. K.: KNU. P.33-36 [in Russian].

13. Makeshina Y. (2014). The representation of motherhood in feminist philosophy by Y.Kristeva // Grani. Scientific-theoretical and public political almanac. No. 11 (115). D. P. 29-33[in Russian].

14. Pecherska N. (2012). Mythology of parenthood: an analysis of the discursive production of an ideal family / Journal of Social Policy Studies. P. 10. № 3. P. 323 - 342 [in Russian].

МАКЕШИНА Ю. В. - кандидат філософських наук, дочент кафедри соиіальногуманітарних наук Придніпровської державної академії фізичної культури і спорту (Дніпро, Україна) E-mail:makeshina@i.uaORCID 0000-0002-2879-2930 


\section{МІФОЛОГЕМИ І МИФООБРАЗИ МАТЕРИНСТВА В ДИСКУРСАХ ТА НАРАТИВАХ СУЧАСНӦ̈ ФІЛОСОФІЇ І КУЛЬТУРИ}

Анотація. Актуальність дослідження в тому, що аналізуються існуючі в культурі міфологеми і міфоообразів ( «жінка-мати», «жінка-трудівниия» $i$ m. Д.), Які виробляють «природний» для нас світ, одночасно усуваючи з поля бачення альтернативні можливості ї̈ влаштування. Проблематізіруя иңю очевидність, осмислюючи виключені владою можливі значення, можна передбачити наслідки певних дискурсивних концептів, при иьому руйнуючи ӥх ідеологічну закритість, «природність» $i$ само очевидність пропонованих конструкиій. Постановка завдання полягає в філософському осмисленні специфіки концептуалізаиї материнства як складного смислового поля, яке визначається характером тендерних відносин. Предмет дослідження - трансформації соиіальних форм $і$ діспозітіва у філософській проблематиці материнства, їх репрезентація в дискурсах $i$ наративах сучасної філософії $i$ культури. Аналіз останніх досліджень і публікацій. Важливими для намого дослідження $\epsilon$ роботи Дж. Батлер, С. Раддік, Л. Ірігарей, Е. Сікс, Ю. Кристевої Ч. Лемерт, Е. Сремія, П. Дейчер, Л. Ніколсон і ін., Які визначають дослідження материнства з точки зору проблем ідентичності / суб'єктивності, що є одним з основних теоретичних напрямків постмодерну. Дослідники гендеру, враховуючи постмодерністський імпульс, схильні реконструювати жіночу ідентичність, біологію та «матеріальність», незважаючи на «вічну тасмницю» ессениіального тіла.

Ключові слова: материнство, суб'єктивність, репрезентація, дискурсивна практика, перформативність.

МАКЕШИНА Ю В. - кандидат философских наук, доџент кафедры социальногуманитарных наук Приднепровськой государственной академии физической культуры и спорта (Днепр, Украина)

E-mail:makeshina@i.uaORCID 0000-0002-2879-2930

\section{МИФОЛОГЕМЫ И МИФООБРАЗЫ МАТЕРИНСТВА В ДИСКУРСАХ И НАРРАТИВАХ СОВРЕМЕННОЙ ФИЛОСОФИИ И КУЛЬТУРЕ}

Аннотация. Актуальность исследования в том, что анализируются существующие в культуре мифологемы и мифообразы («женщина-мать», «женщина-труженица» и т. д.), которые производят «естественный» для нас мир, одновременно устраняя из поля видения альтернативные возможности его устройства. Проблематизируя эту очевидность, осмысливая исключенные властью возможные значения, можно предвидеть последствия определенных дискурсивных концептов, при этом разрушая их идеологическую закрытость, «естественность» и самоочевидность предлагаемых конструкций. Постановка задания заключается в философском осмыслении специфики конщептуализации материнства как сложного смыслового поля, которое определяется характером гендерных отномений. Предмет исследования - трансформачии сочиальных форм и диспозитивов в философской проблематике материнства, их репрезентачия в дискурсах и нарративах современной философии и культуры. Анализ последних исследований и публикаций. Важныли для нашего исследования являются работы Дж. Батлер, С. Раддик, Л. Иригарей, Э. Сиксу, Ю. Кристевой Ч. Лемерт, Е. Иеремия, П. Дейчер, Л. Николсон и др., которые определяют исследование материнства с точки зрения проблем идентичности/ субъективности, что является одним из основных теоретических направлений постмодерна. Исследователи гендера, учитывая постмодернистский импульс, склонны реконструировать женскую идентичность, биологию и «материальность», несмотря на «вечную тайну» эссенциального тела.

Ключевые слова: материнство, субъективность, репрезентация, дискурсивная практика, перформативность.

Стаття рекомендована до публікаџї д.філософ.н., проф. В.Г.Воронковою (Запоріжжя, 